\title{
Urdimento
}

\section{ESPAÇO TEATRAL E PERFORMATIVIDADE. ESTRATÉGIAS E TÁTICAS NA CENA MODERNA E CONTEMPORÂNEA}

\author{
Evelyn Furquim Werneck Lima
}

\section{Resumo}

O presente artigo tem por objetivo discutir os conceitos de sistemas disciplinares e de performatividade no espaço cênico, buscando relacioná-los no âmbito da História do Espetáculo, com fundamento nas teorias e conceitos de Michel Foucault e Michel de Certeau. Ambos permitem uma abordagem teórica sobre a questão dos métodos e da disciplina do ator. Conclui-se que a técnica de improvisação freqüente na cena moderna e contemporânea parece refutar os conceitos foucaultianos, aceitando, ao contrário, a prática das táticas propostas por Certeau.

Palavras-chave: espaço teatral, sistemas disciplinares, história do espetáculo.

\begin{abstract}
The present article focuses in the discussion of concepts of discipline and performativity in the scenic space, trying to relate them in the context of the Performing Arts History, based in the theories and concepts of Michel Foucault and Michel de Certeau. Both allow a theoretical approach on the subject of the methods and the actor's discipline and performing. The conclusions are that the technique of the modern and contemporary scene seems to refute Foucault's concepts, accepting, to the opposite, the practice of the tactics proposed by Certeau.
\end{abstract}

Keywords: theatrical space, disciplinary systems, performing arts history.

O presente artigo tem por objetivo discutir os conceitos de sistemas disciplinares e de performatividade ${ }^{2}$ no espaço cênico, buscando relacioná-los na História do Espetáculo.

A História Cultural - vertente nascida na École des Annales-, com Marc Bloch e Lucien Fèbvre, nos anos 1930, e desenvolvida por Jacques Le Goff, Georges Duby, Pierre Bourdiu e, mais recentemente, Roger Chartier, foi atravessada
${ }^{1}$ Evelyn Furquim Werneck Lima é professora Associada do Centro de Letras e Artes e do Programa de Pós-Graduação em Teatro (UNIRIO).

Membro do Centre de Recherches Interdisciplinaires sur le Monde Lusophone (Paris X-Nanterre). Pós-doutora em Artes e doutora em História Social (UFRJ/EHESS).

Coordenadora do Laboratório de Estudos do Espaço Teatral. Pesquisadora do CNPq e da FAPERJ.

${ }^{2} 0$ termo

performatividade, nascido e

desenvolvido entre os estudos da performance, indica um "fazer como", "um fazer fazendo como". Designa as relações de simulação estabelecidas entre o autor/ator/performer com o real - quer através de recursos ficcionais quer autoinduzidos, visando iludir, fazer crer/ enganar 0 espectador e ou até a si mesmo, através de simulações.

Disponível em http:// www.ceart.udesc.br, acessado em 25.set.2008. 


\section{Urdimento}

${ }^{3}$ Foucault tenta analisar, definir, 0 solo epistemológico que serviu de base para rupturas, 0 nascimento de novos saberes e, finalmente, o papel do homem e das ciências humanas a partir do século XIX. por duas personalidades que a meu ver são dois furacões no meio das teorias e filosofias históricas: Michel Foucault e Michel de Certeau. Ambos permitem uma abordagem teórica sobre a questão da performatividade e da disciplina do ator.

Decidi discutir este tema, pois nos anos que se seguiram às publicações e palestras destes dois autores, foram radicalmente alterados não só conceitos da História tout court, porém da História de todas as atividades culturais, entre elas a do Teatro e, por conseqüência, da História do Espetáculo.

Uma das discussões mais polêmicas é encontrada na obra de Foucault intitulada $A$ Palavra e as Coisas, na qual o autor chama atenção para a questão da linguagem, mais precisamente, discute a emancipação da linguagem em relação às coisas. Segundo ele, não haveria mais unidade entre as coisas e a linguagem, unidade perdida no tempo, unidade que se deu no período clássico da história, e que na era moderna se esfacela. Esta afirmativa deflagra o paroxismo da fragmentação, que têm pautado as artes contemporâneas (FOUCAULT: 2002).

Para Foucault, ainda no século XIX, Nietzsche teria sido o primeiro filósofo a trazer a linguagem para o cerne de todas as questões, a propor uma reflexão radical sobre a linguagem. Antes negligenciada como objeto de estudo filosófico, a linguagem constitui hoje o centro da curiosidade do pensamento contemporâneo, passando a ocupar um lugar central na produção de reflexão, arte, cultura.

Este autor defende que após a ruptura com a regra da "representação" e de uma "unidade" que não pode ser restaurada (FOUCAULT, 2002: 419), os "modos de ser passaram a ser múltiplos". Acredita que houve uma ruptura da ordem clássica, um fracionamento da linguagem e uma unidade perdida da linguagem. A questão que aflora hoje é "seria o personagem teatral uma unidade?" Qual a unidade possível hoje? ${ }^{3}$ Segundo o autor, cada época se caracteriza por uma configuração geral do saber comum aos vários saberes particulares, a qual determina o que pode ser pensado, como pode ser pensado, dentro de critérios particulares.

Além da questão da emancipação da linguagem, em sua obra Vigiar e Punir, escrita em 1975, Foucault defende, sobretudo, que o poder se instala na horizontalidade do sujeito individualizado, modelando seu corpo até à passividade. Uma anatomia do poder define o poder que se pode ter sobre o corpo, "aumentando as forças do corpo (em termos econômicos de utilidade) e diminuindo essas mesmas forças (em termos políticos de obediência)". Acrescenta que, “(...) a coerção disciplinar estabelece no corpo o elo coercitivo entre uma aptidão aumentada e uma dominação acentuada" (FOUCAULT, 1987: 127). 
Vigiar e punir é o relato das formas que produziram o indivíduo, tornado normatizado por um poder maior que ele. Entretanto, para refutar esta disciplina corporal do indivíduo face à sociedade e as instituições, destaco o também francês Michel de Certeau, que, em sua obra A Invenção do cotidiano, de 1980, conceitua as práticas das estratégias e táticas, demonstrando que o corpo pode transgredir a disciplina e dar conta das artes de fazer (CERTEAU, 1994: 21). Este pensador demonstra que um jogo que táticas silenciosas e sutis se insinuam quando o corpo ou o indivíduo não deseja se submeter às estratégias. Tratarei mais tarde destas questões quando falar de performatividade.

Ao investigar a cena teatral entre 1970 e 1990, principalmente na Europa e EUA, o teórico Hans-Thies Lehmann identificou que aqueles espetáculos teriam como principal característica comum o rompimento com os conceitos utilizados no "teatro dramático", o qual define como "pensado tacitamente como um teatro do drama". Ele inclui entre os fatores teóricos conscientes as categorias "imitação" e "ação". Este autor afirma que "o teatro dramático está subordinado ao primado do texto”. (LEHMANN, 2007: 25)

Não creio que se possa generalizar este primado do texto com o que Lehmann conceitua como "teatro dramático" e que este teria cedido lugar ao “teatro pós-dramático” após os anos 1970, pois o teatro em cena é considerado diferente da literatura dramática há muito tempo.

Entendo que houve uma passagem conflituosa do campo dos signos lingüísticos para o campo dos signos visuais, mas diferentemente de justificar esta mudança apenas quando surgiu a figura do encenador, ou defender esta transformação apenas na segunda metade do século XX, já identifico uma demarcação relevante desta "batalha" desde os trabalhos do autor inglês Ben Jonson e do arquiteto e cenógrafo Inigo Jones, como também afirmam Oddey e White, referindo-se às montagens encenadas nos Court Masques, ainda no século XVII, quando as peças escritas pelo primeiro eram radicalmente transformadas quando encenadas (ODDEY e WHITE, 2008: 145).

Em recente estudo, Oddey e White traçam um brevíssimo, porém detalhado panorama da questão. Reafirmam que o ponto crucial da atividade teatral acontece no palco e esta atividade é uma experiência visual apresentada em três dimensões e que "refletem a identidade cultural da sociedade que o está assistindo” (ODDEY e WHITE, 2008: 145).

Apesar de citar Brecht como um marco das bases do teatro pósdramático, Lehmann, alega que Brecht não pertence a essa nova estética marcada por uma absoluta liberdade no que tange à construção cênica, sem se subjugar a modelos, formas ou fontes. Para o autor alemão, as encenações de Brecht estavam sempre presas ao texto escrito. Assim como Gerd Borheim, 


\section{Urdimento}

concordo que Brecht utilizava "uma gramática, um todo completo e exato de regras e métodos”. Entretanto, o próprio crítico argumenta que, partindo da racionalidade, Brecht provoca "uma cisão entre o espetáculo e o personagem, a cena e o texto, e esta cisão vai se refletir também na relação do público com o espetáculo" (BORNHEIM, 2001: 27).

Para Pavis, na tradição ocidental o texto dramático permaneceu por muito tempo como um dos componentes essenciais da representação. Entretanto, após as mudanças de paradigmas e a possibilidade de o encenador imprimir no texto encenado a marca de sua visão pessoal, o texto dramático foi deixado à disposição dos filólogos, passando-se da filologia à cenologia (PAVIS, 2003:185).

Citando como exemplo as encenações de Vilar, Jean-Jacques Roubine alega que o teatro contemporâneo contrapõe à literatura dramática uma nova história teatral: uma história das formas, das buscas, das inovações do palco (ROUBINE, 1998: 57) e Pavis defende que a encenação hoje não é mais a passagem do texto à cena e que o texto não deve ser o pólo de atração para o ato da representação (PAVIS, 2003:192).

\section{Espaço teatral e performatividade: diálogos}

A experiência espacial, tanto no edifício teatral como fora dele, dispõe de duas possibilidades, entre as quais todas as teorias do espaço podem oscilar: (i) Concebe-se o espaço como um espaço vazio que se deve preencher; (ii) Considera-se o espaço como invisível, ilimitado e ligado a seus utilizadores, a partir de coordenadas, de seus deslocamentos, de sua trajetória, como uma substância “não a ser preenchida, mas a ser estendida”. A essas duas concepções antitéticas do espaço correspondem duas maneiras diferentes de descrevê-lo: o espaço objetivo externo e o espaço gestual.

Pavis considera o espaço objetivo externo como o espaço visível, frontal muitas vezes, preenchível e descritivo, onde ele distingue duas categorias:

- o lugar teatral, ou seja, o prédio e sua arquitetura, sua inscrição na cidade, mas também o local previsto para a representação ou ainda

- o espaço cênico: lugar no qual evoluem os atores e o pessoal técnico: a área de representação propriamente dita e seus prolongamentos para coxia, platéia e todo o prédio teatral (PAVIS, 2003:141-142)

As formas de lugar teatral foram se modificando de acordo com cada cultura e cada temporalidade. Na linguagem dos espetáculos, as relações espaciais criadas surgiram a partir da organização do espaço cênico, mais 


\section{Urdimento}

especificamente, do desenvolvimento da arquitetura da casa de espetáculos. $\mathrm{Na}$ Grécia clássica as artes cênicas demandaram o anfiteatro grego. No palco principal apenas os protagonistas ocupavam esta faixa entre o palco e o público e tinham como função representar os comentários e reações do povo perante os nobres e os deuses. Havia, assim, uma grande interatividade entre os artistas e o público. O mesmo acontecia nos teatros em semi-círculos e anfiteatros romanos, os quais, apesar de não serem mais escavados nas rochas e sim edificados sobre estruturas em arcos, apresentavam sempre um palco tipo arena.

Durante a Idade Média, o teatro profano era perseguido pelo Cristianismo, havendo permissão da Igreja apenas para realizar os "Mistérios" no adro ou no interior do edifício religioso. Ainda no medievo, os atores tiveram que ocupar espaços não muito nobres, como carroças, tablados, praças, não possuindo um espaço específico para apresentar seus espetáculos.

Teatro de criação coletiva, de jogos cênicos sob máscaras e de personagens tipos, que caricaturavam a sociedade, a Commedia dell'arte significou, literalmente, a profissionalização do teatro: os atores ganhavam a sua vida representando tais comédias, ao serem freqüentemente contratados e remunerados para se apresentarem em espaços privados, como nos grandes castelos e palácios. Esses artistas eram capazes de representar comédias, tragédias, tragicomédias, pastorais, além de farsas. Surgiram por volta de 1550 e se eternizaram na historia da cultura.

Desde a proposta do Teatro Olímpico de Vicenza, obra do arquiteto Andréa Palladio inaugurada em 1580, o ator ficava bem próximo à platéia até a adoção do longínquo e frontal palco italiano, cujo ápice é o La Scala de Milão. O corpo dos atores ficava então bem distante para criar espaços de ilusão. (LIMA \& CARDOSO, 2006) O palco italiano foi planejado para criar um ambiente de magia ilusionista, com o palco cênico separado da orquestra e da platéia.

Em obra de referência sobre a arquitetura do espetáculo no Ocidente afirmo que o palco italiano - adotado em todo o mundo ocidental devido à exportação de gosto pelo espetáculo lírico, foi o modelo que se reproduziu por mais de duzentos anos resultando num fenômeno de longa duração na história do espetáculo ${ }^{4}$ (LIMA, 2000: 135). Visando ampliar as dimensões reais do palco, desde o Renascimento, os cenógrafos criaram vários recursos usando grandes cenários, pintados em perspectiva ${ }^{5}$, com a finalidade de criar um efeito de profundidade ilusória. Esta ilusão criada é chamada de espaço virtual. Porém, este espaço perspectivado transformar-se-ia pelas vanguardas do século XX.

Posteriormente, em Das Vanguardas à tradição (2006), discuti as revoluções cênicas do século XX, citando Gordon Craig, cenógrafo e arquiteto que estabeleceu nos anos 1920, um "quinto palco" para substituir os quatro
${ }^{4}$ Em Arquitetura do Espetáculo discuto 0 advento e a permanência do palco italiano, inclusive 0 empréstimo de suas formas aos espaços destinados ao cinema.

${ }^{5}$ Ver tratado de Sebastiano Serlio. 


\section{Urdimento}

tipos de espaços teatrais a) o anfiteatro grego, b) o espaço medieval, c) os tablados da Commedia dell'Arte e d) o palco italiano. Esta proposta do quinto palco representava a substituição de um palco estático por um palco cinético, e para cada tipo de encenação um tipo especial de lugar cênico. A iluminação recebeu um tratamento inédito até então. Craig fez projetar a luz verticalmente sobre o palco e frontalmente por meio de projetores colocados no fundo da sala. A luz dos bastidores e da ribalta foi abolida, numa proposta inovadora e vanguardista. Neste sentido, o teatro teria como objetivo absorver estas novas tecnologias para transcendê-las, problematizando assim as tecnologias de comunicação na cultura contemporânea.

O crítico Edélcio Mostaço afirma que a partir da implosão do espaço proposta pelo conceito de encenação ou mise-en-scène ao final do século XIX, quando André Antoine fez considerações a respeito, houve uma revolução no espaço da cena no que tange a) ao papel e a função da quarta parede; b) à definição do espaço cênico como contraponto ao espaço narrativo; c) à disciplina dos atores,

O espaço cênico passa a ser vislumbrado, desde então, como uma galvanização das forças atuantes no espaço narrativo, uma busca de adequação entre os meios (da infra-estrutura da linguagem cênica, da iluminação e da cenotécnica, etc) e os fins (a articulação dos signos dentro de um código cênico esuaspossiveis decodificaçõespelo espectador) a conformar a substância última do fenômeno teatral. Especial ênfase é então dispensada aos intérpretes, à noção de ensemble, à administração do elenco; evitando proeminências que comprometessem o conjunto artístico e a coerência de cena. Não se tratava de um "rebaixamento" da condição do ator, mas do redimensionamento de sua função dentro do espetáculo, alinhando-o aos demais possiveis narrativos da linguagem cênica. Com estas renovadas abordagens o teatro passa então a ser considerado como o espaço da representação, -- e não mais da apresentação do mundo ("o grande teatro do mundo" de matriz barroca) --, enfatizando o que possui de ficcional, narrativa artificiosa e produzida, universo propedêutico de vida; cabendo ao encenador formalizar a linguagem e conduzir este processo (MOSTAÇO, s/d).

Desde então, o teatro não se propõe a ocupar apenas o espaço físico - real, cotidiano, concreto-, mas busca extrapolá-lo e, mesmo fazendo uso do espaço real, tem a intenção de criar um espaço onde simbolismos possam ser revelados. Os diretores, quando criam os espaços da cena, produzem sentidos, construídos a partir de uma experiência particular. Considero que os sentidos que os artistas criam através do espaço em suas obras se reportam às experiências espaciais já vividas ou almejadas. Estas experiências são re-elaboradas, constituindo-se de memórias e de desejos do artista (BACHELARD, 1993). 


\section{Urdimento}

O teatro, a dança, o cinema e o circo, entre outras artes, desenvolvemse no tempo e no espaço. Para Patrice Pavis, a aliança de um tempo e de um espaço constitui o que Mikail Bakthin, na literatura, chama de cronotopo, que vem a ser a unidade na quais os índices espaciais e temporais formam um todo inteligível e concreto. Aplicados ao teatro, a ação e o corpo do ator se concebem como o amalgama de um espaço e de uma temporalidade: o corpo não está apenas no espaço, ele é feito de espaço e feito de tempo. Este espaço-tempo é tanto concreto (espaço teatral e tempo da representação) como abstrato (lugar funcional e temporalidade imaginária). A ação que daí resulta é ora física, ora imaginária. O espaço-tempo-ação é percebido como um mundo concreto e como um mundo possível imaginário.

Nos anos 1970, com as performances e os happenings, o teatro e a dança utilizaram espaços não tradicionais e romperam limites em concordância com uma época, que aproximava arte e vida e que questionava as relações de poder e o lugar das coisas. Brigava-se com o autoritarismo, invadindo-se os espaços "formais", como os próprios museus, galpões e praças públicas.

Em 1969, o diretor Luca Ronconi exibiu a peça Orlando Furioso, espetáculo simultâneo em vários tablados, tal como Artaud previra nos anos 1930. (ROUBINE, 1998:105-109) Três anos depois, em 1971, Ariane Mnouchkine apresentou a peça 1789 - encenada na Cartoucherie de Vincennes - local no qual o público fica em pé e a ação se desloca através de passarelas, de um tablado para outro, em várias cenas fazendo o papel do povo de Paris. Durante o espetáculo, os espectadores participam da festa e do foguetório da tomada da Bastillha, ou seja, uma festa dentro da festa (ROUBINE, 1998: 114).

Louvando a peça 1789 - uma encenação que nega a estruturação cênica ilusionista-, Lehmann afirma que estes tablados e passarelas e "as massas de espectadores aglomerando-se e dispersando-se por entre eles conferem ao teatro uma atmosfera semelhante à do circo", mas que ao mesmo tempo apropriam-se do um espaço público, das ruas e praças da Paris revolucionária (LEHMANN, 2007: 266). Na verdade, a cidade e seus espaços públicos abrigam hoje inúmeros espetáculos, aumentando a performatividade no teatro contemporâneo.

Em 1989, durante a entrevista concedida a Gael Breton e publicada em Theatres, Ariane Mnouchkine introduziu o conceito de espaço "encontrado" (BRETON, 1989 apud ODDEY e WHITE, 2008: 148). O termo "espaço encontrado” era incompreensível para muitos arquitetos de teatro, porém para os artistas experimentais e vanguardistas, o "espaço encontrado" anunciava claramente que o teatro contemporâneo é diferente do que era ou ainda é representado nos edifícios teatrais tradicionais ${ }^{6}$. O conceito de "espaço encontrado" consiste em um uso criativo de espaços inusitados, isto é, ambientes cujo potencial dramático dependerá da mão do artista, isto é,

${ }^{6}$ Vale lembrar que nas Escolas de Arquitetura no Brasil, o tema edifício teatral é sempre projetado a partir do programa de um teatro à italiana. 


\section{Urdimento}

a criação do artista modificando, transformando, (re) elaborando o espaço e interferindo no projeto. Esse conceito propiciou a idéia de que "o espetáculo já não deveria mais ser limitado ao palco, mas deveria invadir o espaço inteiro" (ODDEY e WHITE, 2008: 148).

\section{Espaço gestual e disciplina}

Mas Pavis também identifica o espaço gestual - o que mais interessa a este ensaio, como o espaço criado pela presença, posição cênica e os deslocamentos dos atores: espaço emitido e traçado pelo ator, induzido por sua corporeidade, espaço evolutivo suscetível de se estender ou se retrair. A experiência cinestésica do ator é sensível em sua percepção do movimento, do esquema temporal, do eixo gravitacional, do tempo-ritmo. Dados que só pertencem ao ator, mas que ele transmite ao espectador. A sub-partitura na qual o ator se apóia (pontos de orientação no espaço, momentos fortes que facilitam sua ancoragem no espaço-tempo) fornece um percurso e um trajeto que se inscrevem no espaço tanto quanto o espaço se inscreve neles. $\mathrm{O}$ espaço centrífugo do ator se constitui do corpo para o mundo externo. $\mathrm{O}$ corpo encontra-se prolongado pela dinâmica do movimento. O corpo do ator em situação de representação é um corpo que tende a expressar o mais fortemente possível suas atitudes, escolhas, sua presença. (PAVIS, 2003: 142)

O espaço ergonômico do ator, seu ambiente de trabalho e de vida, compreende a dimensão proxêmica (relação entre as pessoas), háptica (maneira de tocar os outros e a si mesmos) e cinéstésica (movimento de seu próprio corpo). No entanto, este espaço ergonômico tem sido diferenciado nos processos de criação de diretores e grupos de teatro ao longo do século XX.

Para Stanislavski o ator manifesta-se pela ausência de tensão muscular, o corpo se sente livre para submeter-se às ordens do artista. Como ele próprio orientava seus atores, pedia-lhes para reparar que "a dependência do corpo em relação à alma é de particular importância em nossa escola de arte. A fim de exprimir uma vida delicadíssima e em grande parte subconsciente, é preciso ter controle sobre uma aparelhagem física e vocal extraordinariamente sensível, otimamente preparada" (STANISLAVSKI, 1968: 44-45).

Destacam-se entre os ensinamentos de Stanislavski: a luta contra o clichê, a busca da sinceridade; o estabelecimento das vontades da personagem para motivar o jogo do ator; a elaboração de um subtexto para exprimir o que se encontra nas entrelinhas, nos silêncios, um clima favorável à emoção cênica, meios de desencadear uma emoção verdadeira no ator. Apesar de afirmar que “em todo ato físico há um elemento psicológico”, ele reconhece que é possível provocar, pela via exterior, uma grande intensidade física. A participação física 
do ator é conseqüência dos passos dados internamente: circunstâncias dadas, imaginação e emoção, ligam-se automaticamente às sensações produzidas no corpo do ator e o impulsionam às ações exteriores.

Seu Método das Ações Físicas parte do princípio de que, se se consegue criar o corpo de um personagem necessariamente termina-se, por seu intermédio, conhecendo e vivenciando também sua alma, pois "o elo entre o corpo e a alma é indivisível. (...) Todo ato físico, exceto os puramente mecânicos, tem uma fonte interior de sentimento". Ministrou técnicas de "movimento plástico", levando os atores a criarem formas, nunca desprovidas de sentido. O corpo pode levar o ator a encontrar a verdade interna, porque basta que o ator em cena perceba "uma quantidade mínima de verdade orgânica, em suas ações ou em seu estado geral, para que instantaneamente suas emoções correspondam à crença interior na autenticidade daquilo que seu corpo está fazendo" (STANISLAVSKI, 1972: 147).

Outro adepto da disciplina do ator é Meyerhold (1874-1940), para quem o movimento cênico é o mais importante dos elementos da cena, e o ator tem que se apropriar de um código baseado em princípios técnicos muito bem determinados. Nos anos de 1916 e 1917, Meyerhold exigia dos atores que cursassem disciplinas diversas como dança, música, atletismo ligeiro, esgrima; trabalhava com a Commedia dell'Arte e com o drama hindu e criou o método da Biomecânica, um sistema de treinamento que leva o ator a se desenvolver a tal ponto que possa exprimir sinteticamente a substância social da personagem. Com vistas a que o intérprete possa expressar um sentimento não é necessária nenhuma mobilização interior, basta que ele se atenha aos reflexos físicos. $\mathrm{O}$ ator precisa praticar esportes e treinar intensivamente o corpo, capacitando-o a reagir aos estímulos mais imprevistos com toda precisão, sem intervalo de tempo para qualquer tipo de reflexão. Aldomar Conrado afirma que na técnica de Meyerhold, para representar o medo, o ator não deve começar por sentir medo (viver o medo e depois correr). Ele deve de início começar a correr (reflexo) e sentir medo depois que ele se viu a correr (CONRADO, 1969: 158).

Como diretor teatral ele reestruturou a cena, desconstruiu a caixa cênica e abandonou o conceito de "uma caixa sem a quarta parede". Mais precisamente ele buscou inspiração no espaço teatral espanhol dos corrales, da Commedia dell'Arte e, seguramente do teatro da antiguidade.

Já Artaud pregava que o ator deveria desenvolver as potencialidades orgânicas de forma a ultrapassar o comportamento natural e cotidiano, para que acabasse atingindo o espectador. $\mathrm{O}$ autor considerava o mundo "como se de um lado estivesse a cultura e do outro a vida; e como se a verdadeira cultura não fosse um meio refinado de compreender e exercer a vida” (ARTAUD, 1993: 04). 


\section{Urdimento}

A alma, concretizada no corpo, pode ser fisiologicamente reduzida a uma meada de vibrações, adquirindo assim uma materialidade na qual o ator há de acreditar. Se a alma dispõe dessa dimensão corpórea, o ator pode dominála partindo de seu físico. O "tempo das paixões" pode ser conhecido pela respiração, pois ao alterá-la, é possível alterar estados interiores; com uma modificação proposital da respiração, novos estados interiores podem ser descobertos e dominados pelo ator. O que ele pretende são gestos purificados, gestos essenciais que busquem sua linguagem autônoma, significando por si mesmos. Para que isso seja possível, a alma deve estar presente, unificada ao corpo, em permanente transformação. Trata-se, portanto, de deixar o próprio ator utilizar suas táticas e suas emoções podem fluir.

No que tange às emoções do personagem, Brecht quer o ator distante - e muito mais distante ainda de suas emoções particulares. No ator brechtiano, o corpo retém as características de atuante e de narrador. Deve tornar-se um espectador atento de si mesmo. $\mathrm{O}$ teatro de Brecht pretende deixar à mostra o processo de feitura das ações e reações humanas num contexto histórico claro. Esse tipo de ator atua sem a quarta parede, demonstra consciência de que está sendo observado, ao mesmo tempo em que observa a si mesmo enquanto trabalha. O gesto, para ele, pretende ser uma mostra das relações sociais presentes na caracterização de um papel. Para Brecht "a dicção" e o "gesto" precisam ser cuidadosamente selecionados, e, devem ter amplitude. Como o interesse do espectador é canalizado exclusivamente para o comportamento das personagens o "gesto" destas personagens tem de ser significativo. Em O que éo teatro épico, Walter Benjamin, afirma a propósito da teoria de Brecht, que:

O gesto é o material do teatro épico, que tem a missão de utilizar adequadamente este material. Face às declarações e afirmações profundamente enganadoras das pessoas, por um lado, e ao caráter impenetrável de suas ações, por outro, o gesto tem duas vantagens. Primeiro só em certa medida pode ser imitado, e isto é tanto mais difícil quanto mais banal e habitual ele for. Em segundo lugar, tem, ao contrário das ações e realizações das pessoas, um começo e um fim determináveis. Esta característica de delimitação rigorosa de cada elemento de uma atitude, que, no entanto, surge como um todo, e é um dos fenômenos dialéticos fundamentais do gesto (BENJAMIN, 1970: 40).

Em fins de 1950, Grotowski se orienta para um teatro-acontecimento. O diretor estabelece uma relação inusitada ao propor que "o teatro é o encontro do ator com o espectador", justificando a invasão do ator para dentro do espaço reservado à platéia, fazendo do público, uma peça chave para os dramas encenados. Incentivava o ator a detectar resistências de toda ordem e a lutar para ultrapassá-las. O seu treinamento realizava-se pela "via negativa", pois 
Grotowski pretendia anular o tempo entre o surgimento de um impulso e sua realização exterior. Em suas pesquisas investigou o Nô, o Kathakali e a Ópera de Pequim e inspirou-se nos princípios da composição artificial, ou seja, da estruturação disciplinada do papel. Através de uma formalização inicialmente exterior e bastante exigente do ponto de vista técnico, pode-se chegar ao espiritual. O princípio da expressividade, para ele, liga dois conceitos dicotômicos, auto-penetração e artificialidade, pois, quanto mais nos absorvemos no que está escondido dentro de nós, no excesso, na revelação, na auto-penetração, mais rígidos devemos ser nas disciplinas externas; isto quer dizer a forma, a artificialidade, o ideograma, o gesto (GROTOWSKI, 1968: 23).

Para Grotowski, o ator "não deve usar seu organismo para ilustrar um movimento da alma; deve realizar esse movimento com o seu organismo". O processo de cada ação deve ser todo visível: o local onde tem início o movimento, o momento do seu término e o início de uma nova ação. Desse modo o ator percebe que há um movimento interno que ocorre antes do movimento real, uma preparação orgânica que demanda uma mobilização de todo o organismo. $\mathrm{O}$ diretor acredita que o cansaço físico colabora para burlar as resistências da mente e acaba induzindo o ator a ser mais autêntico.

Além de estimular certa liberdade do ator, este diretor dispensa estruturas arquitetônicas e os dispositivos habitualmente colocados a serviço do teatro. A busca grotowskiana, concentrada no aprofundamento da relação entre o ator e o espectador, define-se como um "teatro pobre", e recusa a ajuda de qualquer maquinaria (ROUBINE, 1998: 101-102). Em alguns espetáculos o público está tão próximo que pode tocar o ator, aumentando a dinâmica centrípeta de energias co-vivenciadas, como alega Lehmann:

"Quando o afastamento entre atores e espectadores é reduzido de tal maneira que a proximidade física e fisiológica (respiração, suor, tosse, movimento muscular, espasmos, olhar) se sobrepõe à significação mental, surge um espaço de intensa dinâmica centrípeta em que o teatro se torna um movimento das energias co-vivenciadas, e não mais dos signos transmitidos... Já o espaço de grandes proporções representa uma ameaça para o teatro dramático por seu efeito centrífugo" (LEHMANN, 2007: 268).

Dirigido por Judith Malina e Julian Beck, desde 1947, o grupo Living Theatre traz o conceito de um "teatro vivo", norteador tanto do trabalho quanto da vida de ambos. Influenciado inicialmente por Piscator e Brecht e com referências poéticas, filosóficas e teatrais de outras fontes, o grupo direcionouse para uma obra e uma postura política diferentes desses mestres, passando, então, a pregar, a partir de inúmeras encenações e peças, a revolução não- 


\section{Urdimento}

${ }^{7} J$ ean-François Lyotard alega que, "o corpo pode ser considerado como 0 hardware do complexo dispositivo técnico que é o pensamento". Segundo as idéias de Lyotard, o software humano, no caso da linguagem, não pode existir sem que haja um hardware, ou seja, o corpo. Para ele, seria conveniente tomar o corpo como exemplo na produção e programação das inteligências artificiais, já que 0 hard/soft humano é muito complexo e heterogêneo.

(LYOTARD, 1989: 21) violenta e o anarquismo. parte do princípio de que a presença do ator em cena estabelece uma relação com o espectador, e que essa presença é tanto mais materialmente verdadeira quanto mais forem desenvolvidas e utilizadas pelo ator a linguagem corporal e gestual. A ligação ator-público acontece ora no confronto aberto via agressão, ora pela comunhão. A palavra é tratada em suas possibilidades materiais de produção sonora. O trabalho corporal do Living liga-se estreitamente ao que se convencionou chamar de Expressão Corporal, que implica a mistura de arte-vida, com poucas regras técnicas e muita liberdade de improvisação, refletindo teorias que Certeau reafirmou nos anos 1980.

Para Robert Wilson, diretor também contemporâneo,

"I do movement before we work on the text. Later we'll put text and movement together. I do movement first to makes sure it's strong enough to stand on its own two feet without words. The movement must have a rhythm and structure of its own. It must not follow the text. It can reinforce a text without illustrating it. What you hear and what you see are two different layers. When you put them together, you create another texture" (WILSON apud HOLMBERG: 136).

Suas peças primam pela movimentação lenta, pela quase imobilidade. Um vocabulário foi organizado a partir de exploração individual de ações muito simples: pular, dar um passo à frente, correr, voltar à posição inicial. O diretor sugere que não se deve impor a quem quer que seja, seus próprios movimentos. Estimulando em seus atores a descoberta de padrões próprios de movimentos, prefere, portanto, movimentos naturais soltos ${ }^{7}$.

No teatro e Centro de Estudos do Odin Teatret na Dinamarca, dirigido por Eugênio Barba desde 1961, a Antropologia Teatral é utilizada com a finalidade de induzir a descobertas que possam ser úteis ao ator na elaboração de sua arte. O trabalho corporal adotado tem origens em Grotowski e no teatro Kathakali: uma disciplina rigorosa e métodos precisos de codificação da arte da atuação. Barba trabalha com um princípio que trouxe da Índia: "depois de muitos anos de árdua formação, o ator Kathakali desenvolve não só uma excepcional capacidade física, mas, sobretudo, a habilidade para viver como ator sem viver para os espetáculos" (BARBA, 2007: 30).

Muitos exercícios são usados e os que contêm elementos acrobáticos são chamados de biomecânicos. Visam a vencer o medo, chegar a uma completa disponibilidade para obedecer aos impulsos, mobilizar totalmente a energia em ações inesperadas, em reações imediatas. O intérprete compõe uma partitura a partir de signos físicos, em conformidade com as intenções que deseja imprimir ao seu trabalho; essas intenções devem achar seu ritmo próprio. Ao diretor cabe apenas a ajudar a fixar a seqüência. 


\section{Urdimento}

Barba estimula que os atores inventem seus próprios exercícios, pois "chegou à conclusão que mais importante do que a forma de exercício, é a motivação tenaz de executá-lo até seus limites extremos, contribuindo desta forma para a sua mutação" ( BARBA, 2007: 30).

Esta breve análise quanto aos métodos adotados demonstra a diversidade de percepção de alguns encenadores quanto à disciplina do ator. Tanto as questões espaciais, quanto as da performatividade em muito se modificaram a partir destes pressupostos que de certa maneira revolucionaram a História do Teatro, pois o espectador passa a ser constantemente acossado pelo espetáculo, que lhe permitia ver e ouvir, mas também vivê-lo e fazê-lo (ROUBINE, 1998:101).

Em sua obra recente, Fios do Tempo, o diretor teatral Peter Brook recorre ao, às técnicas desenvolvidas por Grotowski e às tradições orientais para explicitar melhor a performatividade do ator. Entre os exercícios propostos destaca-se o Tai Chi Chuan (para aumentar a consciência corporal e desenvolver a sensibilidade) e tudo aquilo que ajude o ator a ampliar sua gestualidade. Brook teme o ator que, desejando agir o mais naturalmente possível, lance mão dos clichês (seu próprio condicionamento gestual). $\mathrm{O}$ ator é visto como um artista que, além de imprimir em sua criação seus impulsos interiores, há de ser o responsável pela seleção da melhor forma, de modo que um gesto ou um grito se torne "um objeto que ele descobre e ele mesmo modela" (BROOK, 2001:198).

Antes de montar sua companhia, Brook realizou investigações sob o ponto de vista do corpo. Os atores exploraram em cada uma das diferentes culturas os gestos mais ordinários (como apertar as mãos ou colocar a mão no coração); trocavam movimentos de dança de várias tradições; exprimiam-se com palavras e sílabas das línguas de cada um; deixavam que gritos se desenvolvessem gradualmente em padrões rítmicos; usavam varas de bambu para fazer geometrias silenciosas no ar entre outros exercícios (BROOK, 2001: 245). Percebe-se que o ator pode fazer uso das táticas certeaudianas a partir dos conceitos de Geertz, que julga impossível pensar a natureza humana como exclusivamente biológica e desvinculada da cultura, sendo que o homem se constitui nesta relação interativa entre componentes biológicos e socioculturais.

Após as pesquisas sobre o corpo, Brook dedicou-se a explorar o espaço. A ferramenta utilizada para a promoção desses encontros era sempre a improvisação, e ocorria em lugares como albergues; nos arredores de Paris e em enfermarias de hospitais. Após viajar pela África, Ásia e América do Norte, Brook instalou-se finalmente num teatro à italiana situado na periferia de Paris, onde criou seu Centro de Pesquisas ${ }^{8}$.
${ }^{8} 0$ teatro Bouffes $d u$ Nord era um teatro sem cadeiras, sem palco e com um chão coberto de crateras, "um espaço íntimo, de modo que o público tem a impressão de que compartilha a mesma vida que os atores". A planta foi adaptada à semelhança do teatro elisabetano, The Rose, e a "sua intimidade não tolera qualquer subestima; ele requer dos atores a energia capaz de preencher um pátio, aliada à naturalidade de representar em uma sala pequena" (BROOK, 2001: 245). 


\section{Urdimento}

${ }^{9}$ Os principais conceitos discutidos por estes encenadores/ cenógrafos estão nos Anais do Colloque Architecture et Dramaturgie, Paris: CNRS, 1948.

${ }^{10}$ Para Marcel Mauss, "o corpo é o primeiro e mais natural instrumento do homem (...) 0 primeiro e mais natural objeto técnico" (MAUSS, 1974: 372). Mauss parte do pressuposto que 0 homem não é um ser dissociável, "no fundo, corpo, alma, sociedade, tudo se mistura", sendo que os movimentos do corpo podem ser vistos como tradutores de elementos de uma cultura ou sociedade. Cada corpo expressa diferentemente a história de um povo e o uso que fazem de seus corpos. Ou seja, o corpo é um objeto técnico, um objeto cultural, que evolui e se insere na cultura.
Muito se discutiu sobre a questão da interatividade entre atores e espectadores, que era diminuta no teatro à italiana, mas bem mais adequada quando o público se reunia para assistir ao espetáculo no entorno de uma arena, onde todos, democraticamente tinham poltronas não distribuídas segundo uma hierarquia de classes. Nos espetáculos teatrais apresentados em palcos em arena corpo do espectador participa da peça e dos movimentos do atores. Estes aspectos já haviam sido abordados desde os anos 1940 por Étienne Souriau, que escreveu o conhecido artigo $\mathrm{O}$ cubo e a esfera e por André Barsacq que realizou diferentes experiências em parcerias com Jacques Copeau na França dos anos $1930^{9}$.

\section{Mais táticas do que estratégias}

Novos conceitos, como performance, improvisação e happenings ampliam os limites da cena, no último quartel do século XX. Estabeleceramse alguns princípios inusitados como: repetições, estruturas não-lineares, acontecimentos simultâneos e a mistura de linguagens: teatro, dança, poesia, música, artes plásticas.

Além das demais artes ou mídias que integram o teatro contemporâneo, o trabalho do performer ou do ator demanda algum tipo de preparação. No teatro, os diretores exploram e instigam questões existenciais, promovendo o resgate dos registros de experiências vividas, de imagens, sons, percepções, odores, bem como para novas experiências. Essas expressões exigem do ator uma imersão nas investigações.

Mais recentemente, no que tange à preparação do corpo do ator, Sonia Azevedo busca encontrar os elementos básicos de um trabalho corporal que ajudem o ator a desempenhar cada vez melhor o seu papel. Preparar o corpo, ampliar seus horizontes perceptivos e aprimorar sua sensibilidade, auxiliam a busca de uma intimidade cada vez maior do artista com ele próprio (AZEVEDO, 1998: XX). Esta autora propõe que o trabalho corporal deva ser pensado a partir da desconstrução da memória corporal, arraigada em tensões acumuladas ao longo dos anos.

Marcel Mauss explica que o corpo é um transmissor de técnica e tradição. A técnica corporal consiste "nas maneiras" como os homens e as sociedades se serviram de seus corpos, podendo ser transmitida através de gerações, constituindo então uma tradição. O corpo e os movimentos humanos são expressões simbólicas de uma sociedade, já que podem ser passadas às gerações futuras por meio de símbolos. (MAUSS, 1974: 372) A técnica que um corpo comporta pode ser transmitida de forma impressa ou oral, conceituada, descrita, relatada; mas pode ainda ser transmitida por atitudes corporais e pelo próprio movimento ${ }^{10}$. 
Portanto, para Azevedo, a postura corporal não consciente e movimentos recorrentes daquele individuo devem ser abandonados para possibilitar a pesquisa objetivando a "metamorfose". Deve-se então buscar uma "reeducação corporal, que passa, em seu início pela deseducação, ou seja, pela constatação de que uma série enorme de marcas arraigadas que terão de ser trocadas por novas atitudes corporais" (AZEVEDO, 1998: 138-140). Pode-se inferir que esta deseducação vai produzir táticas individuais que burlam as metodologias disciplinares.

Na vida cotidiana, as práticas da expressão corporal, colocadas para restituir ao corpo seu poder imaginário, demonstram o quanto essa obsessão por uma redescoberta da primitividade concerne a múltiplas técnicas. Tal conclusão, comungada por Michel de Certeau, foi contrária à postulada por Michel Foucault em sua obra Vigiar e Punir, na qual ele afirmava a passividade e disciplina do homem em relação às práticas e aos produtos impostos (LIMA \& CALDEIRA, 2007).

Para Certeau, as pessoas ordinárias reinventam a cada dia maneiras próprias de se apropriarem desses produtos, a partir de astúcias que compõem uma rede "antidisciplinar". Certeau acredita que nas práticas corporais "táticas silenciosas e sutis se insinuam e propõe algumas maneiras de pensar as práticas cotidianas dos consumidores supondo no ponto de partida que elas sejam do tipo tático". A idéia não é criar um modelo engessado de conjunto das práticas, porém, ao contrário, especificar esquemas operacionais e procurar se existem categorias comuns entre eles e ver se, com tais categorias, se pode explicar o conjunto das práticas corporais (CERTEAU, 1994:21).

\section{A guisa de conclusões}

O processo de recriar a experiência no palco ou em outro lugar teatral pode ser cansativo, mas é imprescindível na História de Espetáculo, pois após cada experiência o registro da situação vivida se inscreve em cada célula, em cada músculo do corpo, numa memória celular corporal. Com o auxílio técnico do diretor, os movimentos dos atores surgidos no laboratório são retomados e realizados de forma consciente, estabelecendo uma seqüência. A performatividade surge, nessa "verdade" vivida e registrada como uma escrita cênica corpórea que passa a ser o tex to dramatúrgico. Infelizmente, nem todos os atores conseguem se expor visceralmente e produzir arte com esta exposição, nem todos os diretores conseguem ajudar o ator a realizar este processo. Mas a técnica de improvisação livre parece refutar os conceitos foucaultianos, aceitando, ao contrário, a prática das táticas propostas por Certeau.

$\mathrm{Na}$ contemporaneidade, ocorre a ruptura com as meta-narrativas. Ocorre um rompimento com a maneira de ler e compreender o mundo, que deixa 


\section{Urdimento}

${ }^{11}$ Em Teatro de invasão: redefinindo a ordem da cidade, Carreira desenvolve um conceito de queas "formas espetaculares não se contentam em estar nas ruas, mas procuram incorporar na cena os fluxos da rua, ou, por outro lado, subverter estes fluxos fabricando rupturas dos ritmos cotidianos" (2008: 69). de ser o universal metafísico da unidade, constância, regularidade, para tornarse a diversidade e a descontinuidade fragmentária defendidas por Foucault.

Uma vez que deixa de ser totalidade e razão global, o contexto - tão caro à modernidade-, cede espaço ao intertexto, ou seja, o entrecruzamento de múltiplas linguagens. A idéia de totalidade perdeu significação e abandonouse a história linear e seqüencial, em que pesem as críticas às afirmações de Foucault. Modificam-se as formas de representação de mundo referenciadas em princípios e origens. Não há mais raízes ou lógicas totalizantes. Some o padrão, fica o múltiplo. O espaço teatral e a performatividade entre ator e espectador estão relacionados a uma maior liberdade, às junções de várias artes em cena e, muitas vezes, à apropriação e à invasão da cidade, como defendeu recentemente André Carreira ${ }^{11}$ (2008).

A linguagem teatral ganha um novo sentido. A contemporaneidade mudou a maneira como se passa a ver o teatro, visto que hoje, considera-se todo meio e modo de representação como linguagem. Uma paisagem, uma pintura, um espaço vivido, um movimento, são texto e intertexto, formas de linguagem. No teatro contemporâneo é necessário estar sempre alerta às diferentes formas de expressão e aos seus respectivos significados.

\section{Referências bibliográficas}

ARTAUD, Antonin. O teatro e seu duplo. Trad. Teixeira Coelho. São Paulo: Martins Fontes, 1993.

AZEVEDO, Sônia Machado de. O papel do corpo no corpo do ator. São Paulo: Perspectiva, 1998.

BACHELARD, G. APoética doEspaço. Trad.AntôniodePáduaDanesi. SãoPaulo: Martins Fontes, 1993. (Coleção Tópicos).

BARBA, Eugenio. O Quarto fantasma. Urdimento, dezembro 2007, n. 9, pp. $29-42$.

BENJAMIN Walter. O que é o Teatro Épico? (Um Estudo Sobre Brecht). Teatro e Vanguarda. Lisboa: Presença, 1970.

BORNHEIM, Gerd. A estética brechtiana entre cena e texto. In Folhetim 10, mai-ago 2001, pp. 22-31.

BROOK, Peter. Fios do Tempo. Trad. Carolina Araújo. Rio de Janeiro: Bertrand Brasil, 2001.

CARREIRA, André. Teatro de invasão: redefinindo a ordem da cidade. In: LIMA, Evelyn. Espaço e Teatro: do edifício teatral à cidade como palco. Rio de Janeiro: 7 Letras, 2008, pp.67-78.

CERTEAU, Michel de. A Invenção do cotidiano: 1. Artes de fazer. Trad. Ephraim Ferreira Alves. Petrópolis, RJ: Vozes, 1994. (1 ${ }^{a}$ edição francesa 1980) 
CONRADO, Aldomar. O Teatro de Meyerhold. Rio de Janeiro: Civilização Brasileira, 1969.

FOUCAULT, Michel. Vigiar e Punir. Nascimento da prisão Trad. Lígia M. Ponde Vassalo. Petrópolis: Vozes, 1987. ( $1^{\mathrm{a}}$ ed. francesa 1975)

As Palavras e as Coisas: uma arqueologia das ciências humanas.

Trad. Salma Tannus Muchail. $8^{\mathrm{a}}$ ed ( $3^{\mathrm{a}}$ tiragem), São Paulo: Martins Fontes, 2002. (Coleção Tópicos)

GROTOWSKI, Jerzy. Em Busca de um Teatro Pobre. Rio de Janeiro: Civilização Brasileira, 1968.

HOLMBERG, Arthur. The Theatre Of Robert Wilson. Cambridge: Cambridge UP, 1996.

LEHMANN, Hans-Thies. Teatro pós-dramático. Trad. Pedro Süssekind. São Paulo: Cosac Naify, 2007.

LIMA, Evelyn Furquim Werneck. Arquitetura do Espetáculo. Teatros e cinems na formação do espaço público da Praça Tiradentes e da Cinelândia. Rio de Janeiro: Editora da UFRJ, 2000.

. Espaço e Teatro. Do edifício teatral à cidade como palco. Rio de Janeiro: 7 Letras, 2008, pp. 144-161.

LIMA, Evelyn \& CALDEIRA, Solange. Espaço, Corpo e Memória. Conferência apresentada no Colóquio Internacional: O Corpo e suas Traduções. UNIRIO/ PARIS X (Nanterre), 17-19 dezembro 2007. (texto inédito)

. Em busca de novos paradigmas: concepções inusitadas no teatro europeu. In Das vanguardas à tradição. Rio de Janeiro: 7 Letras, 2006, pp. 17-34. LYOTARD, Jean-François. O inumano: considerações sobre o tempo. Lisboa: Editorial Estampa, 1989.

MAUSS, Marcel. Sociologia e antropologia. Trad. Mauro Almeida, São Paulo: EPU/Edusp, 1974, v. 1.

MOSTAÇO, Edélcio. O texto e a encenação - percursos. Disponível em $<$ http://www.furb.br/especiais/textos $>$. Acessado em 24 set.2008.

ODDEY, Alison; WHITE, Christine. As potencialidades dos espaços. In: PAVIS, Patrice. A análise dos espetáculos. Trad. Sergio Sálvia Coelho. São Paulo: Perspectiva, 2003.

ROUBINE, Jean-Jacques. A Linguagem da Encenação Teatral (1880-1980). Trad. Yan Michalski. Rio de Janeiro: Jorge Zahar Ed.,1998.

STANISLAVSKI, Constantin. A Preparação do Ator. Rio de Janeiro: Civilização Brasileira, 1968. . A Criação de um Papel. Rio de Janeiro: Civilização Brasileira, 1972. 